\title{
Human pancreatic islet function at the onset of Type 1 (insulin-dependent) diabetes mellitus
}

\author{
I.Conget $^{1}$, J.Fernández-Alvarez ${ }^{1}$, J.Ferrer ${ }^{1}$, Y.Sarri $^{1}$, A.Novials $^{1}$, N.Somoza $^{3}$, R.Pujol-Borrell $^{3}$, R. Casamitjana $^{2}$ \\ and R. Gomis ${ }^{1}$
}

${ }^{1}$ Endocrinology and Nutrition Unit, Hospital Clinic, Barcelona, Spain

${ }^{2}$ Hormonology Unit, Hospital Clínic, Barcelona, Spain

${ }^{3}$ Immunology Unit, Hospital Germans Trias i Pujol, Badalona, Spain

\begin{abstract}
Summary. Viable human pancreatic islets isolated from a recent-onset Type 1 (insulin-dependent) diabetic patient were used to perform in vitro studies. Pre-proinsulin mRNA and insulin content, as well as insulin response were analysed. Insulin response to glucose and forskolin was completely absent in diabetic islets, as compared to control islets. Insulin content was reduced to only one-third of control values $(395.0 \pm 3.5$ vs $989.0 \pm 46.3 \mu \mathrm{U} /$ islet $)$ and $20.7 \pm 3.9 \%$ of islets from the diabetic pancreas contained insulin-positive cells in immunofluorescence studies. Northern blot analysis re-
\end{abstract}

vealed a severe reduction in the content of pre-proinsulin mRNA in diabetic pancreatic tissue. Our results indicate that although markedly decreased, beta cells in human pancreatic islets at the onset of Type 1 diabetes are still present. Nevertheless, pancreatic islet function is disproportionately impaired with a complete absence of an insulin response.

Key words: Human islets, islet function, onset of Type 1 (insulin-dependent) diabetes mellitus.
Type 1 (insulin-dependent) diabetes mellitus is an autoimmune disease caused by the selective destruction of islet beta cells. Attempts have been made to define the immunopathological aspects of this destruction. This has shown that pancreatic tissue from newly-diagnosed Type 1 diabetic patients presents several distinct features including: severely reduced beta-cell mass, various degrees of expression of MHC class I and class II antigens in islet cells and lymphocytic infiltrates [1-3]. However, the beta-cell secretory function of this clinical entity has only been evaluated in in vivo studies [4].

We report here the first study in which viable human pancreatic islets were isolated from a recent-onset Type 1 diabetic patient and thus were used to perform in vitro functional studies.

\section{Subjects and methods}

After obtaining the family's informed consent and with the approval of the Hospital Ethics Committee, human pancreatic islets were isolated from the pancreas of a islet cell antibody positive 18-year-old woman who had died $6 \mathrm{~h}$ after her admission because of diabetic ketoacidosis. She had been asymptomatic up to 2 days prior to admission when polydipsia, polyuria and polyphagia were observed. Islets were obtained following a modification of Ricordi's automatic digestion technique [5]. The pancreas from the diabetic patient was treated in the same manner as the pancreata obtained from the con- trol cadaveric organ donors with a similar time period between death and pancreas removal. Briefly, after the pancreatic duct was cannulated, Hanks' balanced salt solution (HBSS) at $37^{\circ} \mathrm{C}$ containing $1 \%$ newborn calf serum (NCS; Gibco, Paisley, UK), $2.5 \mathrm{mg} / \mathrm{ml}$ collagenase (Type P; Boehringer Mannheim, Mannheim, FRG) and $0.04 \mathrm{mg} / \mathrm{ml}$ deoxyribonuclease (DNAse I; Sigma, St.Louis, Mo., USA) was injected. The pancreas was loaded into a digestion chamber and was connected to a closed circuit with recircularization of the medium and continuously shaken. Samples were taken every $3 \mathrm{~min}$, stained with dithizone (DTZ; Sigma) and then examined under stereomicroscope. When free islets were detected the digestion was stopped by quickly cooling the digestion chamber. Dispersed pancreatic tissue was washed several times in HBSS by centrifugation at $60 \times g$ at $4^{\circ} \mathrm{C}$. Cell viability was assessed by ethidium bromide/ acridine orange (Sigma) staining.

Cryostat sections of $5 \mu \mathrm{m}$ were dried for $30 \mathrm{~min}$ and stained by an indirect immunofluorescence method using an anti-C-peptide (Pep030, kindly provided by Novo-Nordisk, Copenhagen, Denmark), anti-glucagon (Glu001, Novo-Nordisk) and anti-somatostatin (Som018, Novo-Nordisk) antibodies.

Batches of six hand-picked islets of similar size from the digested pancreatic tissue were incubated in a shaking water bath for $90 \mathrm{~min}$ at $37^{\circ} \mathrm{C}$ in $1.0 \mathrm{ml}$ bicarbonate-buffered medium containing bovine serum albumin $(5.0 \mathrm{mg} / \mathrm{ml}$; Fraction $\mathrm{V}$, Sigma) and D-glucose at 5.5 , $11.1,16.7 \mathrm{mmol} / \mathrm{l} ; \mathrm{D}$-glucose $(16.7 \mathrm{mmol} / \mathrm{l})$ plus forskolin $(0.005$ $\mathrm{mmol} / \mathrm{l}$, Sigma). For the first $10 \mathrm{~min}$ of incubation, the vials containing the incubation medium with the islets were gassed with $\mathrm{O}_{2}: \mathrm{CO}_{2}$ (95\%:5\%). At the end of the incubation period supernatants were aliquoted and stored at $-20^{\circ} \mathrm{C}$ until assayed for insulin by an RIA method (CIS, Biointernational, Gif-Sur-Yvette, France). The method allows the determination of $2.5 \mu \mathrm{U} / \mathrm{ml}$, with a coefficient of 
Table 1. Insulin secretion ( $\mu \mathrm{U}$ insulin $\cdot$ islet $^{-1} .90 \mathrm{~min}^{-1}$, mean \pm SEM) by diabetic and control islets. Control values were obtained from seven pancreata. Number of individual experiments in parentheses

\begin{tabular}{lll}
\hline Stimulus & Diabetic islets & Control islets \\
\hline $5.5 \mathrm{mmol} / \mathrm{l}$ glucose & $1.00 \pm 0.11(4)$ & $10.26 \pm 0.94(29)$ \\
$11.1 \mathrm{mmol} / \mathrm{l}$ glucose & - & $15.60 \pm 1.01(31)$ \\
$16.7 \mathrm{mmol} / \mathrm{l}$ glucose & $0.88 \pm 0.03(4)$ & $21.75 \pm 1.14(30)$ \\
$16.7 \mathrm{mmol} / \mathrm{l}$ glucose + & & \\
$0.005 \mathrm{mmol} / \mathrm{l}$ forskolin & $0.85 \pm 0.01(4)$ & $61.55 \pm 4.20(18)$ \\
\hline
\end{tabular}

variation within and between assays of $6 \%$ and $8 \%$ respectively. Insulin release is expressed in $\mu \mathrm{U}$ insulin $\cdot$ islet $^{-1} \cdot 90 \cdot \mathrm{min}^{-1}$.

Groups of ten islets were disintegrated by ultrasonic disruption (Branson Sonifier 250, London, UK) at $4^{\circ} \mathrm{C}$ in $0.5 \mathrm{ml}$ acid-alcohol solution $[75 \%(\mathrm{v} / \mathrm{v})$ ethanol, $23.5 \%$ bi-distilled water and $1.5 \%(\mathrm{v} / \mathrm{v})$ $10 \mathrm{~N} \mathrm{HCL}$. The homogenates were kept at $-20^{\circ} \mathrm{C}$ until insulin was assayed by RIA. Insulin content was expressed in $\mu U$ of insulin per islet.

Total RNA was isolated by the method of Chirgwin [6]. Briefly, frozen tissue $\left(-70^{\circ} \mathrm{C}\right)$ from the head of the pancreas was disrupted in guanidinium isothiocyanate solution, layered onto a cushion of cesium chloride, and spun in an SW 55 Ti rotor (Beckman, Palo Alto, Calif., USA) at $152,000 \times g$ overnight. The RNA pellet was resuspended, phenol-chloroform extracted, and concentrated by ethanol precipitation. RNA concentration in each sample was determined by optical density at $260 \mathrm{~nm}$. RNA preparations were denatured, electrophoresed through formaldehyde/agarose gels, and transferred to Z probe nylon membranes (Bio-Rad Laboratories, Richmond, Calif., USA). The integrity of the RNA was confirmed in all cases by inspection of the ethidium bromide stained gel. The membranes were hybridized with pre-proinsulin (PHINS 96) and cyclofilin cDNA probes prepared by the random priming method using $\left[{ }^{32} \mathrm{P}\right]$-dCTP. Pre-proinsulin mRNA-cyclofilin mRNA ratios were used to verify the accuracy of the pre-proinsulin mRNA signal.

Results were compared with islets obtained from the pancreas of non-diabetic organ donors, using the same methodology.

\section{Results}

Viability assessed by acridine orange/ethidium bromide staining was $95 \%$ in diabetic islets and greater than $85 \%$ in control islets.

After the digestion the yield obtained was 6400 and $5831 \pm 1081$ EIN (equivalent islet number of standard $150 \mu \mathrm{m}$-diameter) per gramme of tissue processed from the diabetic and control pancreata $(n=29)$, respectively.

Insulin response to increasing glucose concentrations as well as glucose and forskolin combined in the media was completely absent in diabetic islets, as opposed to control islets (Table 1). Insulin content was reduced, but not absent, in diabetic islets, $395.0 \pm 3.5 \mu \mathrm{U} /$ islet $(n=3)$, when compared to normal islets $989.0 \pm 46.3 \mu \mathrm{U} /$ islet (four pancreata, $n=3-4$ replicates per pancreas).

Immunofluorescence staining of sections from the diabetic pancreas revealed that all 371 islets examined contained glucagon-positive and somatostatin-positive cells. Only $20.7 \pm 3.9 \%$ of these islets contained insulinpositive cells.

Northern blot analysis disclosed a severe reduction in the content of pre-proinsulin mRNA in diabetic pancreatic tissue (Fig. 1).

\section{Discussion}

This study describes data concerning pre-proinsulin mRNA and insulin content, as well as in vitro insulin secretion behaviour of human endocrine pancreatic tissue at the onset of Type 1 diabetes. In addition, results obtained from immunological and molecular studies on this tissue have been previously reported [7].

The results obtained from immunofluorescence studies demonstrated the presence of glucagon-positive and somatostatin-positive cells not only in insulin-positive islets but also in non-insulin-containing cell specimens from the diabetic pancreas. This observation rules out the suspicion that the absence of insulin-containing beta-cells in about $80 \%$ of these specimens means that they may not represent true endocrine tissue. In order to further guarantee that what we isolated from the diabetic pancreas were islets, the authors refer to previous experience in which handpicked islets (control islets) were later stained with dithizone and more than $95 \%$ were found to be dithizone positive. Thus the authors feel confident that true islets were employed.

In our study, we observed the absence of an insulin secretory response to both a nutrient and a non-nutrient secretagogue. This could not be explained only by the destruction of beta-cell mass since the reduction of the insulin content of these islets was one-third that of control values. Pre-proinsulin mRNA levels were also clearly diminished. Even so, it is unlikely that the secretory defect was due solely to abnormal transcription and synthesis of the hormone because insulin stores were not depleted. It is worth noting that while just $20 \%$ of the islets from the diabetic pancreas contained insulin-positive cells, insulin content of the islets was $30 \%$ of that observed in controls. This observation implies that two insulin-positive islets from ten randomly selected islets examined for insulin content must contain a normal, or higher than normal, insulin content. However, in the present study we consider that information obtained from measuring insulin content is more accurate than that provided by indirect immunofluorescence staining.
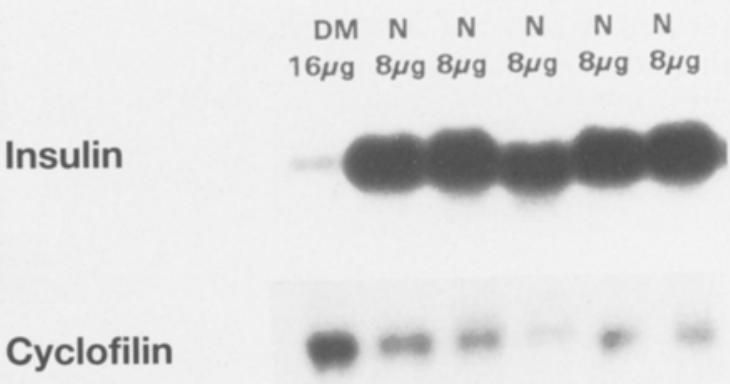

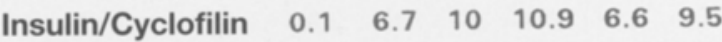

Fig. 1. Northern-blot analysis of pre-proinsulin mRNA (refered to as insulin in the figure) in tissue of recent onset Type 1 diabetic pancreas (DM) and normal pancreas (N). Total RNA isolated from diabetic pancreas $(16 \mu \mathrm{g})$ and from each normal pancreas $(8 \mu \mathrm{g})$ were hybridized with pre-proinsulin cDNA and cyclofilin $c D N A$ 
Altogether, our findings are in agreement with the prevailing view derived from in vivo studies in which the initial phases of Type 1 diabetes are characterized by functional secretory defects in addition to the destruction of insulinproducing islet cells $[1,4]$. Although specific defects in glucose-induced insulin response occur during the early preclinical stages of the disease, it has been shown that a generalized secretagogue insensitivity becomes apparent as the disease progresses [8]. Since Type 1 diabetes is an autoimmune disease, it is not surprising that several factors such as cytokines have been suggested to be involved in the initial secretory alterations [9]. Moreover, a preferential destruction of a high glucose-sensitive beta-cell subpopulation with preservation of less glucose-sensitive cells, could be occurring at early stages of the disease [10].

In summary, although clearly diminished, it is possible to find insulin producing cells in human pancreatic islets at the onset of Type 1 diabetes. Nevertheless, islet function is disproportionately impaired with a complete absence of an insulin response.

Acknowledgements. We are indebted to Ms L. Alcalde, Dr. G. Soldevila and Dr. M. Vives from Hospital Germans Trias i Pujol (Badalona), Ms E. F. Usac from Hospital Clinic (Barcelona) for their collaboration in human islet isolation. We thank the Surgery Department and Transplantation Unit of Hospital Clinic (Barcelona), for the procurement of pancreatic glands. We thank Novo-Nordisk for providing us with the antibodies employed in immunofluorescence studies. This study was supported in part by grants from Hospital Clínic, the Fondo de Investigaciones de la Seguridad Social (FISs Exp: 90 E-12626-D) and a fellowship (to Y.S., J.F.A. and A.N) of the Fundació per l'estudi de les malalties endocrino-metabòliques.

\section{References}

1. Hanafusa T, Miyazaki A, Miyagawa J et al. (1990) Examination of islets in the pancreas biopsy specimens from newly diagnosed type 1 (insulin-dependent) diabetic patients. Diabetologia 33: 105-111
2. Gepts W (1965) Pathologic anatomy of the pancreas in juvenile diabetes mellitus. Diabetes 14:619-633

3. Foulis AK, Stewart JA (1984) The pancreas in recent-onset type 1 (insulin-dependent) diabetes mellitus: insulin content of islets, insulitis and associated changes in the exocrine acinar tissue. Diabetologia 26: 456-461

4. Ganda OP, Srikanta S, Brink SJ et al. (1984) Differential sensitivity to $\beta$-cell secretagogues in "early", type I diabetes mellitus. Diabetes 33: 516-521

5. Vives M, Sarri Y, Conget JI et al. (1992) Human islet function after automatic isolation and BSA gradient purification. Transplantation 53: 243-245

6. Chirgwin J, Przybyla AE, MacDonald RJ, Rutter WJ (1979) Isolation of biologically active ribonucleic acid from sources enriched in ribonuclease. Biochemistry 18: 5294-5299

7. Somoza N, Vargas F, Martí M et al. (1992) Immunohistopathologic and molecular studies on the pancreas of a newly diagnosed type 1 diabetic patient. Diabetologia 35 [Suppl 1]: A41 (Abstract)

8. Bardet S, Rohmer V, Maugendre D et al. (1991) Acute insulin response to intravenous glucose, glucagon and arginine in some subjects at risk for type 1 (insulin-dependent) diabetes mellitus. Diabetologia 34: 648-654

9. Sandler S, Andersson A, Hellerström C (1987) Inhibitory effects of interleukin 1 on insulin secretion, insulin biosynthesis and oxidative metabolism of isolated rat pancreatic islets. Endocrinology 121:1424-1431

10. Pipeleers D (1987) The biosociology of pancreatic B-cells. Diabetologia 30: $277-291$

Received: 5 October 1992

and in revised form: 18 November 1992

Dr. R. Gomis

Endocrinology and Nutrition Unit

Hospital Clínic

Villarroel 170

E-08036 Barcelona

Spain 